\title{
Seed losses during the harvesting of oilseed rape (Brassica napus L.) at on-farm scale
}

\author{
L. Pari, A. Assirelli, A. Suardi, V. Civitarese, A. Del Giudice, E. Santangelo \\ Consiglio per la ricerca e la sperimentazione in agricoltura, Unità di ricerca per l'ingegneria agraria \\ (CRA-ING), Monterotondo (Roma), Italy
}

\begin{abstract}
In the Italian environments, the rapeseed (Brassica napus L.) is subjected, at ripening, to a seed shattering causing significant losses that reduce the yield and increase the oilseed rape seedbank in the soil. Meteorological events and mechanical harvesting are the main factors affecting the extent of seed dispersal. Lacking the availability of works investigating the actual losses during the harvest at large scale, the Consiglio per la sperimentazione e la ricerca in agricoltura, Unità di ricerca per l'ingegneria agraria (CRA-ING) has conducted a study in order to determine the effective seed losses at on-farm scale.

The amount of losses of two combine headers, traditional for wheat and specific for oilseed rape harvest, was compared. The rapeseed header had a hydraulic sliding cut-bar and two vertical electric blade on both sides in order to reduce the pulling and tearing action between the cut-off plants and those still standing. The seed losses were evaluated before and during the harvesting by using plastic trays placed on the ground within the crop rows. The trays were arranged in a layout allowing the estimation of the seed losses of three different sectors of the combine headers.

The results have demonstrated that, at farm level, the use of a specific oilseed rape header adapted and optimized for the crop requirements allows to obtain a level of seed losses ( $0,97 \%$ of total production), below the values reported in literature. For rapeseed, the higher losses are localized at the final parts of the head, where the plants are strictly intertwined.
\end{abstract}

Correspondence: Alberto Assirelli, Consiglio per la ricerca e la sperimentazione in agricoltura, (CRA - ING), Via della Pascolare 16, 00016 Monterotondo (RM), Italy.

Tel. +39.06 .90675211 - Fax: +39.06 .90625591$

E-mail: alberto.assirelli@entecra.it

Key words: rapeseed, seed losses, energy crops, combine header

Acknowledgments: this work was supported by the Italian Ministry of Agriculture under the BIOENERGIE Project (Energie da biomasse agricole e forestali:miglioramento ed integrazione delle filiere dei biocarburanti e della fibra per la produzione di energia elettrica e termica).

(C) Copyright L. Pari et al., 2013

Licensee PAGEPress, Italy

Journal of Agricultural Engineering 2013; XLIV(s2):e126

doi:10.4081/jae.2013.s2.e126

This article is distributed under the terms of the Creative Commons Attribution Noncommercial License (by-nc 3.0) which permits any noncommercial use, distribution, and reproduction in any medium, provided the original author(s) and source are credited.

\section{Introduction}

The prospect of using rapeseed (Brassica napus L.) oil for biodiesel production has expanded, in recent years, the cultivation area in Italy, with new sources of income for the farmer. Since previously the oil was destined for food use, the cultivation of rapeseed is well-known and the crop has been introduced in most cropping systems (Venturi and Venturi, 2003; Cosentino et al., 2008). A peculiar trait of rapeseed physiology is the acropetal pattern of fruit (silique) ripening, leading to the simultaneous presence at harvest of both mature and unripe siliques. Upon a short period of rapid dehydration, the siliques may loss until $60 \%$ of their water content becoming prone to shattering (Squires et al., 2003) and leading to a significant seed losses.

The loss of seed raises the level of weed infestation for several years, also causing a decrease of yield for the following crop. Gulden et al. (2003) observed that, due to the yield losses, the average canola seedbank was approximately 20 times the normal seeding rate. As a consequence the specie can persist as volunteer for many years, because the seeds stored into the soil maintained remarkable ability to germinate up to ten years and beyond (Lutman et al. 2003).

Unlike others agricultural contexts, in Italy the oilseed rape is harvested performing just one stage, using the combine harvester with different types of heads and accessories. The timing of harvest is of utmost importance and requires a careful control of both the limitation of losses caused by natural dehiscence and the reduction of the percentage of immature green seeds (Szpryngiel et al., 2003) more sensitive to be damaged (Szwed and Lucaszuk, 2007) and with a lower quality when used for biofuel production (Kachel-Jakubowska and Szpryngiel, 2008). The optimization of machine setting heavily affects all the possible causes of seed dispersal and, hence, the overall performance of the crop.

Aim of this study was the evaluation of the yield reductions of the oilseed rape caused by harvest operations and the identification of the amount of losses registered by different sectors of the combine in the Italian cultivation area on open field conditions and at on-farm scale.

\section{Material and methods}

\section{Crop culture}

This study was carried out during the summer 2007 in Castelnuovo Scrivia, $44^{\circ} 58^{\prime} 53^{\prime \prime} N$ latitude, $8^{\circ} 52^{\prime} 56^{\prime \prime}$ E longitude and $85 \mathrm{~m}$ altitude (Piemonte region, Italy). The experimental field was placed within an area of 16 ha cultivated with oilseed rape. Ten plots ( 5 plots per header), $8 \mathrm{~m}$ wide $\times 50 \mathrm{~m}$ long, were considered and arranged in a randomized block design with two blocks to offset the effect of local variation in yield and density of the culture.

Seedbed was prepared at the end of summer, performing first a ploughing (45 $\mathrm{cm}$ deep) and then a passage with a rotary harrow. Subsequently the common local agricultural practices for oilseed rape 
A

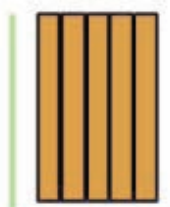

B

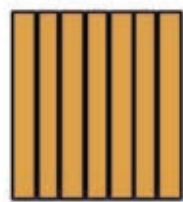

Head $6.18 \mathrm{~m}$
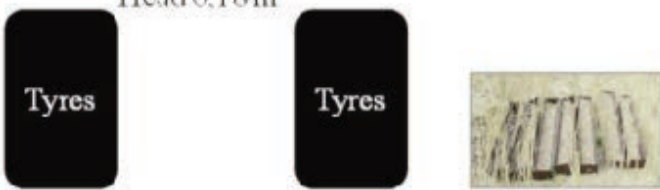

Figure 1. layout of the trays used for the assessment of the seed losses on the ground. The arrangement of the plastic trays inside the canopy is show in the insert.

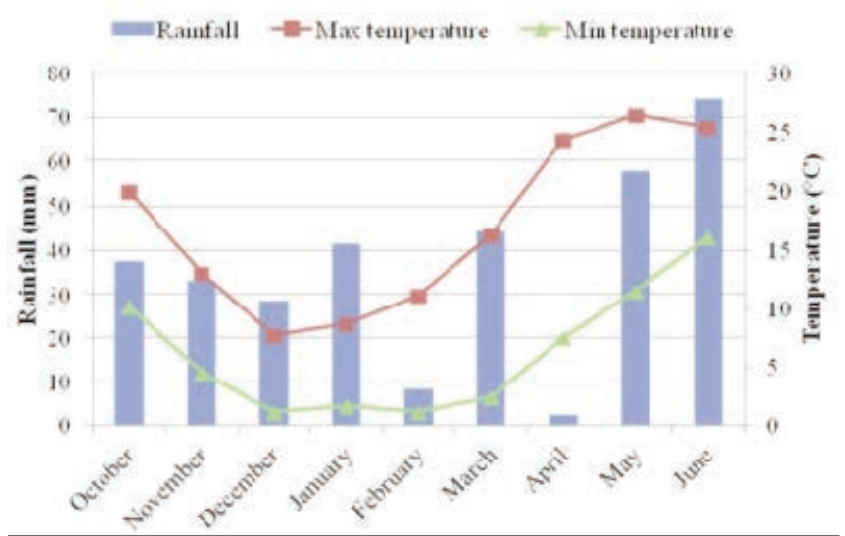

Figure 2. rainfall and temperatures registered for the whole growing season of oilseed rape (October 2006-June 2007) in the experimental field.

cultivation were applied. One month after flowering, the turning of seeds color was checked in the whole field (16 ha) in order to determine the proper harvest timing (30-40\% of seeds with the color turning from green to brown).

Out of the experimental plots, the whole area (16 ha) were harvested using a combine harvester for wheat and the yield (2.945 $t$ ha-1), net of losses, were used as reference value for the calculation of the percentage of losses on the experimental production.

\section{Evaluation of seed losses}

Two different combine headers were compared: a traditional wheat head and a head specifically equipped for rapeseed. This latter mounted a hydraulic sliding cut-bar and two vertical electric blade on both

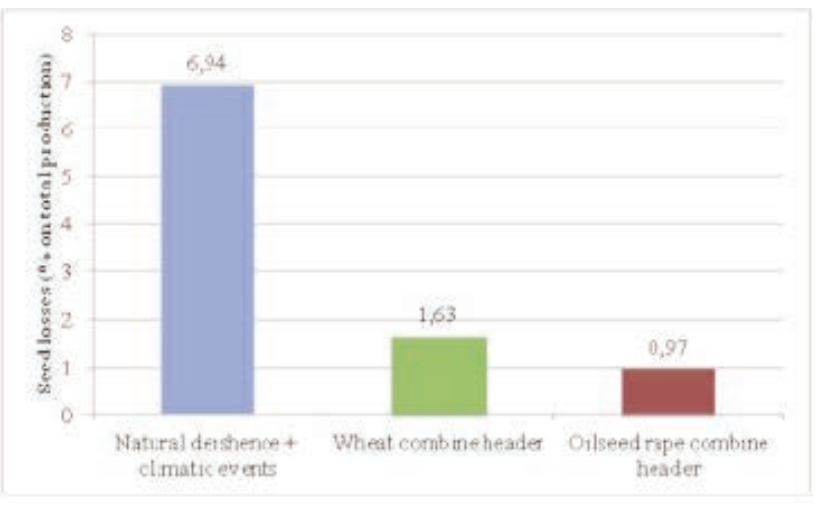

Figure 3. incidence (\%) of losses on total production registered for events independent from harvest and for the two headers regardless the sectors of head.

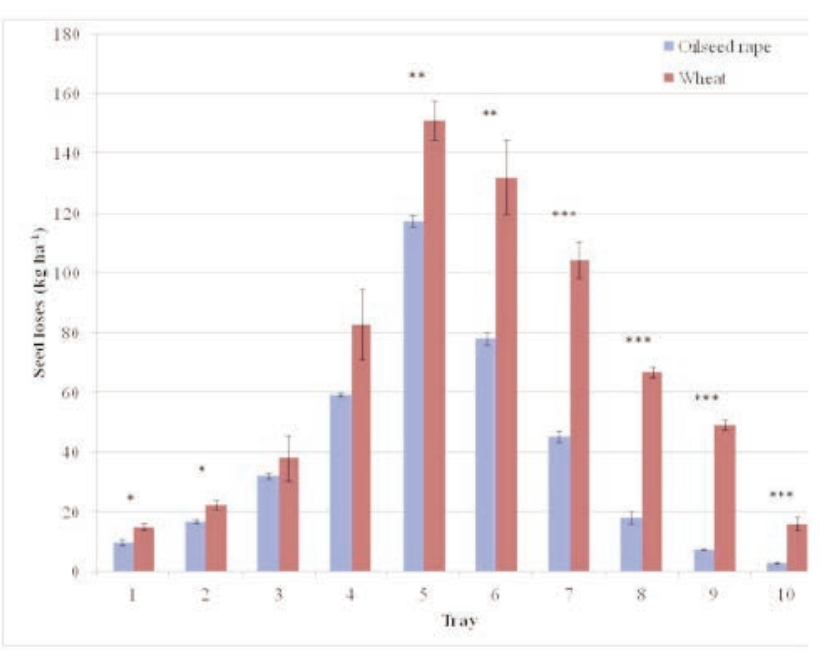

Figure 4. average $( \pm$ S.E. $)$ seed losses $\left(\mathrm{kg} \mathrm{ha}^{-1}\right)$ recorded for each trays placed below the sector $\mathrm{C}$ during the harvest with wheat and oilseed rape headers. Significant differences between headers within tray were determined by Student's t-test. Where reported, ${ }^{*} \mathrm{P}<0.05,{ }^{* *} \mathrm{P}<0.01$ and ${ }^{* * *} \mathrm{P}<0.001$ probability levels.

sides in order to reduce the pulling and tearing action between the cut-off plants and those still standing. For both the heads, three defined sectors (named A, B, C) of the combine were considered (Fig. 1): the horizontal cutter bar and the reel (sector A); the horizontal cutter bar, the reel and the threshing and cleaning system (sector B); the horizontal and vertical cutter bar and the reel, for the rapeseed head, or lo sses due to the horizontal cutter bar and to the effect of tear for the wheat head (sector C). Thus, four sources of losses (A, B, C and B minus A) were assessed for each type of head.

To identify the appropriate work speed, the combine was set in the areas surrounding the plots, maintaining then the same setting for both the wheat and oilseed rape header (Table 1).

Before the harvest, a border strip $12.36 \mathrm{~m}$ wide (two passages of the combine) was removed all around the experimental field. Following 
Table 1: combine harvester used and setting chosen for the study.

\begin{tabular}{|c|c|}
\hline Brand & New Holland \\
\hline Model & CX8090 \\
\hline Engine power (kW) & 337 \\
\hline Rotor diameter (mm) & 750 \\
\hline Rotor length (mm) & 1,560 \\
\hline Straw walker $\left(n^{\circ}\right)$ & 6 \\
\hline Wheat/Oilseed rape header width (m) & 6.18 \\
\hline Rotor speed ( (ad s$\left.^{-1}\right)$ & 440 \\
\hline Fan speed $\left(\mathrm{rad} \mathrm{s}^{-1}\right)$ & 430 \\
\hline Concave clearance (mm) & 37 \\
\hline Upper sieve clearance (mm) & 4 \\
\hline Lower sieve clearance (mm) & 3 \\
\hline
\end{tabular}

Table 3: mean $( \pm$ S.E. $)$ of the total yield losses and difference $\left(\mathrm{kg} \mathrm{ha}^{-1}\right)$ between headers $\left(\Delta_{\mathrm{w}-\mathrm{o}}\right)$ registered for events independent from harvest and for the two headers.

\begin{tabular}{lrrrr}
$\begin{array}{l}\text { Source of losses } \\
\text { n. of samples }\end{array}$ & \multicolumn{3}{c}{$\begin{array}{c}\text { Seed losses }\left(\mathrm{kg} \mathrm{ha}^{-1}\right)^{a} \\
\text { Total }\end{array}$} & $\begin{array}{l}\Delta(\mathrm{W}-0) \\
\text { Natural deishence }+\end{array}$ \\
$\begin{array}{l}\text { climatic events } \\
\text { Wheat combine harvester }\end{array}$ & 110 & $204.34 \pm 15.32$ & \\
\hline Oilseed rape combine harvester & 110 & $28.64 \pm 2.61$ & $* * *$ & 19.32 \\
\hline
\end{tabular}

a Significance of differences between head type for wheat or oilseed rape were determined by Student's t-test. ${ }^{* * *} \mathrm{P}<0.001$ probability level.

Price et al. (1996) and Klinner et al. (1986), small plastic trays (1000 $\mathrm{mm}$ long and $160 \mathrm{~mm}$ wide) were used for the measurement of seed losses and positioned in each plot (Fig. 1).

In order to evaluate the losses not attributable to mechanical harvesting (natural dehiscence and climatic events), on early June, before the appearing of the first ripen siliques, the plastic trays were randomly placed on three assay areas (1 m wide x $1.8 \mathrm{~m}$ long) outside the experimental field (same variety and maturity stage) and removed just before the harvesting.

For evaluating the seed losses during the harvest, the same layout of trays on the ground was adopted for both the heads. The containers were placed $5 \mathrm{~m}$ before the plot end in order to allow the combine to pass over them in full workload (threshing, separating and cleaning at work). In total 250 samples of seeds (one sample from each tray) were collected (Table 2).

The meteorological station of Tortona (Alessandria, Italy), belonging to the regional network of environmental monitoring (ARPA), and placed $2.6 \mathrm{~km}$ far from test area, recorded the meteorological data of the experimental field.

When performed, the statistical analysis of data were made using MSTAT-C statistical package.

\section{Results}

At harvest the crop showed a regular development without lodged areas and with a moisture content of the seeds $(9,44 \%)$ suitable for the harvest operations. The weather was typical of the region, with minimum and maximum temperatures that progressively decreased from October to February and reached the higher values during the harvest
Table 2: Number and distribution of the trays used for the assessment of the seed losses.

\begin{tabular}{|c|c|c|c|c|c|}
\hline \multirow[t]{3}{*}{ Somrce of losses } & \multirow[t]{3}{*}{ Renlicates $(\mathrm{n})}$. & \multicolumn{4}{|c|}{ Samnles (n.) } \\
\hline & & \multicolumn{3}{|c|}{ Combine sector } & \multirow[t]{2}{*}{ Thtal } \\
\hline & & $\mathbf{A}$ & B & C & \\
\hline $\begin{array}{l}\text { Natural deishence and } \\
\text { climatic events }\end{array}$ & 3 & & & & 30 \\
\hline \multicolumn{6}{|l|}{ Header } \\
\hline Wheat & 5 & 5 & 7 & 10 & 110 \\
\hline Rapeseed & 5 & 5 & 7 & 10 & 110 \\
\hline
\end{tabular}

Table 4: mean $( \pm$ S.E. $)$ of total yield losses and difference $\left(\mathrm{kg} \mathrm{ha}^{-1}\right)$ between headers $\left(\Delta_{\mathrm{w}-\mathrm{o}}\right)$ registered for the different combine sectors analyzed.

\begin{tabular}{lrrrr} 
Source of losses & Head type & n. samples & \multicolumn{3}{c}{$\begin{array}{c}\text { Seed losses }\left(\mathrm{kg} \mathrm{ha}^{-1}\right)^{\mathrm{a}} \\
\text { Middle (A sector) }\end{array}$} & Wheat & 25 & $9.97 \pm 0.56 \mathrm{E}$ & $\Delta_{(\mathrm{w}-0)}$ \\
& Oilseed rape & 25 & $8.05 \pm 0.69 \mathrm{E}$ & 1.92 \\
\hline Intersection (C sector) & Wheat & 50 & $67.69 \pm 6.87 \mathrm{~A}$ & \\
\hline & Oilseed rape & 50 & $38.63 \pm 5.02 \mathrm{C}$ & 29.06 \\
\hline $\begin{array}{l}\text { Under combine } \\
\text { (B sector) }\end{array}$ & Wheat & 35 & $49.92 \pm 5.51 \mathrm{~B}$ & \\
\hline & Oilseed rape & 35 & $29.09 \pm 1.84 \mathrm{D}$ & 20.83 \\
\hline $\begin{array}{l}\text { Threshing and cleaning } \\
\text { (B-A sector) }\end{array}$ & Wheat & 25 & $51.95 \pm 5.04 \mathrm{~B}$ & \\
\hline & Oilseed rape & 25 & $26,43 \pm 1.25 \mathrm{D}$ & 25.52 \\
\hline
\end{tabular}

${ }^{a}$ Different capital letters represent statistically significant differences according to the ANOVA at 0.01 probability level (Duncan's test)

phase (Fig. 2). Just before the harvest, the average temperature progressively increased, peaking $\left(30-31^{\circ} \mathrm{C}\right)$ the week preceding the harvest. Concomitantly the solar radiation gradually rose to values above $250 \mathrm{~W}$ $\mathrm{m}-2$, thus promoting the uniform ripening of siliques. It should be underline that after the trays for the monitoring of the natural dehiscence have been placed, at least three significative rainfall events occurred. This brought about a seeds dispersal due to the action of natural dehiscence and climatic events (Table 3, Fig. 3), surely consistent (6.94\% of total production), but expected for the environmental conditions of the area. The two headers showed a different level (statistically significant) of seed losses. The head for oilseed rape allow a containment of seed dispersal equal to $19.32 \mathrm{~kg}$ ha-1, with a decrease of losses from 1,63\% (wheat head) to a level of the $0.97 \%$ of total production (Table 3 , Fig. 3 ).

Also when considering the different sectors monitored, the rapeseed head achieved values of seed losses lower than the ones for wheat, with a difference statistically significant (Table 4). The amount of seed saved was remarkable for the sector $\mathrm{C}$, where the difference between the two head touched nearly $30 \mathrm{~kg} \mathrm{ha}^{-1}$. It should also be noted the difference recorded for the threshing and cleaning apparatus (losses of sector B minus the ones of sector A). The combine header for wheat lost $51.95 \mathrm{~kg} \mathrm{ha}^{-1}$ (corresponding to $1.76 \%$ of the yield) whereas the one for rapeseed $26.43 \mathrm{~kg} \mathrm{ha}^{-1}(0,89 \%$ of the yield) with an improvement corresponding to an average potential increase in yield of $25.52 \mathrm{~kg} \mathrm{ha}^{-1}$. Such result could be explained assuming a better uniformity of feeding assured by the rapeseed head.

The detailed analysis of losses in the $\mathrm{C}$ sector allows to gain additional worthy information (Fig. 4). The reciprocal position of the reel and the cutting mechanism is a key factor: unlike the wheat, for the rapeseed header the losses caused by the reel are intercepted by the head and saved. The difference among the two headers gradually incre ased until the tray number 5 , positioned under the vertical blade. 
In this case it is possible to appreciate the differences between a header that cuts (rapeseed) or a head that pulls and tears (wheat) the plants. It should be highlighted that the seeds collected in the first four trays may be attributed to those lost in the sector A.

The effect that the branching of the rapeseed and the resulting intert wining of the plants may have on the seed losses are emphasized by the asymmetry of losses (Fig. 4). For both the heads, the amount of seeds collected by the trays 6 and 7 was higher than the amount registered for the corresponding and symmetric (respect to the tray n. 5, placed under the vertical blade) trays 4 and 3 . Considering the rapeseed head, this difference among symmetric trays disappeared by moving towards the trays 8 and 9, falling to zero in the last one. On the contrary, the asymmetry of the curve is more pronounced for the wheat header and the gap between the symmetric trays remain always high. This demonstrates as the action of the vertical blade helps to reduce the losses due to the branching of the rapeseed plants.

\section{Conclusions}

To our knowledge, this is the first comparison of seed losses caused by wheat or rapeseed combine headers in open field conditions and at on-farm scale with a more precise quantification of the real yield losses occurring during the industrial cultivation with respect to other similar works (Gulden et al., 2003; Price et al., 1996).

The results underline as the losses are localized, more tha n ever, in correspondence of the final part of the combine header, where the intertwining of plants increases the seed dispersal. The study has shown how the use of a head with advanced blades allowed the substantial reduction of these losses. The application of lateral electric blades achieves the utmost results when the rubbing action (main cause of ground losses) between the cut-off plants and thos e that are still standing is knocked down.

Two other technical aspects should be taken into account. Firstly, the increase of the working width plays an important role for the reduction of seed losses. The positive effect is due to the reduction of the number of passages and the separation lines among a passage and the following, but also to a minor rubbing between the crop and the header. Secondly, the increase of the work width requires the use of lower work speed. The plants are picked up less vigorously, thus assuring a more uniform feeding to the combine and a reduction of the collision with the harvester, a significant factor of seed shattering.
The application of a rapeseed head that may be adapted and optimized for the crop requirements allowed a reduction of seed losses $(0.97 \%$ on total p roduction) at a level below the values reported in literature. The experimental evidences acquired will be of great utility in order to define the aspects of the cultivation technique (such the harvesting) of other crops belonging to the Brassica genus (e.g. B. carinata) botanically and agronomically related and with a potential interest for their use for bioenergy production.

\section{References}

Cosentino S., Copani V., Patanè C., Mantineo M., D’Agosta G.M. 2008. Agronomic, energetic and environmental aspects of biomass energy crops suitable for Italian environments. Italian Journal of Agronomy 3(2):81-95.

Gulden R.H., Shirtliffe S.J., Thomas A.G. 2003. Harvest losses of canola (Brassica napus) cause large seedbank inputs. Weed Sci 51(1): 836.

Kachel-Jakubowska M., Szpryngiel M. 2008. Influence of drying conditions on quality properties of rapeseed. Int. Agrophys. 22(4): 32731.

Klinner WE, Neale MA, Arnold RE, Geikie AA, Hobson RN. 1986. Development and first evaluations of an experimental grain stripping header for combine harvesters. Bedford, UK: National Institute of Agricultural Engineering. 43p. Report NIAE-IER-DN-1316.

Lutman PJW, Freeman SE, Pekrun C. 2003. The long-term persistence of seeds of oilseed rape (Brassica napus) in arable fields. J Agric Sci 141(2): 231-240.

Price J.S., Hobson R.N., Neale M.A., Bruce D.M. 1996. Seed losses in commercial harvesting of oilseed rape. J Agric Eng Res 65(3): 18391.

Squires T.M., Gruwel M.L.H., Zhou R., Sokhansanj S., Abrams S.R., Cutler A.J. 2003. Dehydratation and dehiscence in siliques of Brassica napus and Brassica rapa. Can J Bot 81(3): 248-54.

Szpryngiel M., Wesolowsky M., Szot B. 2003. Economical Technology of Rape seed harvest. Teka Komisji Motoryzacji i Energetyki Rolnictwa Oddział PAN w Lublinie 4: 185-95.

Szwed G., Lukaszuk J. 2007. Effect of rapeseed and wheat kernel moisture on impact damage. Int Agrophys 21(3): 299-304.

Venturi P., Venturi G. 2003. Analysis of energy comparison for crops in European agricultural systems. Biomass Bioenerg 25(3): 235-55. 